\title{
Význam začleňování učiva o technice a praktických činnostech do kurikula základních škol ${ }^{1}$
}

\author{
JiŘí DosTÁL
}

\begin{abstract}
Abstrakt: Současná společnost procházi v globálnim měrítku intenzivnějǐi vlnou promèn, která je charakteristická predevšim nebývalou dynamikou, rozsahem a objemem. Především se jedná o technologické a ekonomické zmèny, které maji podstatný vliv na podobu společnosti. Tempo rozvoje a implementace technologii založených na robotice, umělé inteligenci a informačnich systémech do celé rady oblastí lidského konáni - i prímo nesouvisejicich s technikou - a vedle toho expanze digitálni a sdílené ekonomiky vyvolávaji nové vzdèlávací potřeby, na které je nezbytné neprodlenè reagovat. Je žádoucí pripravovat budouci generace na život $v$ nových podminkách, a proto zde sehrává významnou roli školství. V diusledku toho vyvolané požadavky na provedeni inovaci se týkaji všech úrovni vzdèlávání, avšak zaměrovat se budeme prédevšim na základni školstvi v podminkách České republiky.

Logicky se nabizejí otázky, zda jsou aktuálnè indikované vývojové tendence natolik zásadni, aby byly príčinou pro kurikulárni transformaci podoby vzděláváni, a zda již nastala vhodná doba pro jeji realizaci. Odpovéd' mj. hledáme v mezinárodni poznatkové komparaci s di̛razem na stěžejni kategorie provázané s výukou technických a prakticko-činnostnich predmètů. Rovněž jsou analyzovány koncepčni a provádèci dokumenty souvisejici s realizovanými zmènami vzdèláváni, vč. kličových oborovè-didaktických výzkumně ladèných i teoretických studii. Na základě provedené poznatkové syntézy vyvozujeme a diskutujeme podnèty pro inovativni podobu učiva o technice na základnich školách, které se stává neopomenutelným faktorem prispivajicim k vytváreni komplexu kompetenci nezbytných pro život jedince $v$ moderni společnosti.
\end{abstract}

Klíčová slova: technické vzdèláváni, kurikulum, základní škola, STEM, technická kreativita, praktické cinnosti, technická gramotnost, výchova $k$ volbě povoláni.

\section{ÚvoD}

Technika a technické činnosti jsou nedílnou součástí kultury, která je jako celek členitá a mj. zahrnuje rozsáhlý soubor jevů z oblasti vědění, víry, jazyka, morálky, výroby, umění, zvyků a výchovy. Po celou dobu, co je člověk člověkem,

\footnotetext{
${ }^{1}$ Článek vznikl za podpory vědecko-výzkumného grantového projektu Technická tvorivost žákio základni školy z pobledu genderu financovaného Univerzitou Palackého v Olomouci.
} 
ho ve stále vyšší míre obklopuje a doprovází př̀i řešení stále více životních situací. Některé již bez techniky ani není možné zvládnout anebo by byl lidský potenciál využíván neúčelně (srov. Tondl, 2009). To je jedním důvodů, proč jsou poznatky o technice začleňovány do školního kurikula jako součást obsahu všeobecného, ale i odborného vzdělávání.

$\mathrm{V}$ této studii se budeme zaměřovat na úroveň základních škol, jelikož ty představují jeden z úvodních článků pomyslné páteře profesní orientace a následného odborného vzdělávání, které pod vlivem dynamiky vývoje jednotlivých profesí stále častěji nabývá podobu celoživotního učení se. Představa výchovy již navždy profesně připraveného člověka, at již na středoškolské, vyšší odborné nebo vysokoškolské úrovni, je dnes zcela nereálná. Profesní dráhy se různě větví a člověk za život i několikrát profesi změní, a taktéž působí vývojové trendy, tj. některé profese mohou zcela zaniknout, jiné mohou projít radikální proměnou náplně práce. Není výjimkou, že zcela nové profese vznikají (Lee \& Trimi, 2018).

Obecně je vzdělávání založeno na předávání znalostí, kulturních vzorců a sociální zkušenosti, ke kterým lidstvo $\mathrm{v}$ průběhu svého historického vývoje dospělo, mladším generacím. $\mathrm{V}$ rámci vzdělávání nelze předávat veškeré poznání - není to možné, ale nebylo by to ani smysluplné. $Z$ generace na generaci je sice $\mathrm{v}$ různých podobách předáváno v podstatě veškeré poznání uchovávané prostřednictvím různých médií, avšak my se zaměrujeme pouze na vzdělávání ve významu organizované činnosti. Kurikulum tak rozsáhlé kvantum poznání nemůže pojmout. Proto cíleně uvažujeme jen poznatky významné jednak společensky, ale i z hlediska rozvoje jedince samého, vždy s ohledem na prrítomnost nebo budoucí potřeby a očekávání. Učivo předkládané žákům tedy vzniká zpracováním různých oblastí kultury, tj. vědy, techniky, umění, činností a hodnot, do učebních plánů, osnov, učebnic, do výuky (blíže viz Skalková, 1999). Je přetvářeno věcné a operativní vědění, kterým lidstvo disponuje, stejně jako sociální aktivity, hodnotové orientace a postoje (tamtéž).

$S$ tím souvisí impulz $\mathrm{k}$ napsání této studie, kterým se ve velké míré stala skutečnost, že pod vlivem neadekvátního uplatňování utilitaristických, módních či humanistických tendencí anebo pragmatických názorů může docházet $\mathrm{k}$ neopodstatněnému vytrácení pro všestranný rozvoj žáka významných vzdělávacích obsahů. Neznamená to, že kurikulum by mělo být zakonzervované, nedotknutelné, neměnné, to by nebylo vhodné, naopak musí docházet $\mathrm{k}$ jeho proměnám za současného jemného vyvažování jednotlivých složek tak, aby byl žákovi poskytnut dostatečný prostor pro jeho všestranný rozvoj. Tohoto problému se velmi výstižně dotkl rovněž $P$. Urbánek (2017, s. 307), který poznamenává, že „v českém základním školství lze nalézt skrytější i flagrantní př́klady, kdy bylo skoncováno s nějakým ,nepotřebným učivem, aby se po určité době ukázalo, že pro komplexní kultivaci žáka v kuri- 
kulu přece jen chybí“. Dále pokračuje: „V nedávné minulosti to byl na vyšším stupni základního vzdělávání vyučovací obsah hned celého předmětu pracovního vyučování, který se zdál být $\mathrm{v}$ počítačové době překonaný, zastaralý, obsahem neužitečný, nejspíše i málo atraktivní. Tedy zcela jistě též chápán jako ,neproduktivní. Obrat v náhledu na redukci polytechnického učiva ale náhle způsobilo zjištění o nedostatečné manuální zručnosti absolventů základních škol a zejména jejich tragicky nízký zájem o profesní profilaci směrem $\mathrm{k}$ řemeslu a $\mathrm{k}$ technickým oborům." Odborníci také poukazují na to, že mladá generace se stává manuálně neschopnou (Heller \& Hotová, 2019), stále častěji se hovoří o digitální demenci (Spitzer, 2014) a je znovuobjevováno, že pro zdravý vývoj dítěte je manuální činnost ve smyslu Fröebela, Campeho či Amerlinga nezbytnou. Počítače nevyřeší vše, jen činnosti s počítači nestačí. Již delší dobu je např́ić vyspělým světem usilováno o intenzivnější rozvíjení technické gramotnosti mladé generace (srov. Ingerman \& Collier-Reed, 2011; Ankiewicz, 1995; van Rensburg, Myburgh \& Ankiewicz, 1996; Pudi, 2007; Potgieter, 2012).

Uvedené myšlenky pokládáme za závažné a s ohledem na kurikulární vývoj v České republice vysoce aktuální. To je důvod, proč cílíme na teoreticky zakotvené zdůvodnění významu technického a prakticko-činnostního vzdělávání na základních školách v 21. století, tedy období masového rozvoje robotizace, informatizace, umělé inteligence a tzv. sdílené ekonomiky.

\section{TeCHNICKÉ A PRAKTICKO-ČIN- NOSTNÍ VŠEOBECNÉ VZDĚLÁVÁNÍ NA ZÁKLADNÍCH ŠKOLÁCH}

Kurikulární oblast základního vzdělávání, kam přísluší to, co je podstatou této studie, je mnohdy velmi obtížně vymezitelná. Ne že by hranice neexistovaly, avšak historické události, technologický, ekonomický a společenský vývoj a četné účelové tendence zapříčinily pro člověka stojícího mimo obor obtížnou zřetelnost obrysů vymezujících pole zájmu. To je pravděpodobně také důvodem, proč uvažovaný pojem získává různé konotace. Pro začátek vyjděme $\mathrm{z}$ myšlenek J. Pestalozziho, že dítě by si mělo osvojit základní intelektuální, řemeslné, mravní a náboženské hodnoty (srov. Cipro, 1996). Je možné namítat, že dnešní či budoucí škola má odlišné poslání, avšak požadavek na všestranný, jinak též komplexní rozvoj dítěte je plně oprávněný i v současnosti. Všeobecné vzdělání nelze jakkoli zploštovat potlačováním nebo neodůvodněným posilováním té či oné výchovně-vzdělávací složky na úkor druhých. To by mohlo vyvolat diskontinuitu, ale rovněž zanechat obtížně odstranitelné následky ve vychovávaných a na plnohodnotný život připravovaných jedincích.

Kvůli existenci různých názorových proudů a pohledů na věc samotnou je velmi obtížné najít zastř̌ešující označení pro tuto oblast. Bývají užívány názvy předmětů, jako pracovni vyučováni, technika, praktické činnosti, ruční práce, technická výchova (srov. Dostál, 2018b), přičemž ani 
jeden z nich není všeobjímající. Za účelem plného porozumění je nezbytné proniknout $\mathrm{k}$ hlubšímu pochopení smyslu daného obsahu vzdělávání. Aniž bychom pořadím jakkoli naznačovali významnost, plní technické a prakticko-činnostní ${ }^{2}$ vzdělávání v perspektivním pohledu jen velmi obtížně zastupitelnou funkci. V komplexu vzdělávacích oblastí přispívá k celistvosti udržování a rozvoji kultury jako soustavy sdílených hodnot. Jedinci umožňuje plnohodnotně vrůstat do společnosti, orientovat se ve světě a společně s ostatními jej utvářet a konceptualizovat.

V souvislosti s technickým vzděláváním na základních školách se jeví klíčovým pojem technická gramotnost. Ten mívá různé výklady, avšak podobně jako R. A. Dixon (2013) vnímáme technickou gramotnost jako zásadní formu gramotnosti pro 21. století, srovnatelnou s matematickou, prýrodovědnou, informační nebo čtenářskou gramotností. Bývá vymezován jako schopnost používat, řídit (ovládat), hodnotit a pochopit technologie (srov. ITEA, 2007). Vymezením technické gramotnosti se mj. dříve zabývali N. K. G. Ramirez a L. F. M. Perez (2015), J. Štofa (1992) nebo J. Kropáč (2004). Poslední dva z uvedených autorů na ni nahlížejí jako na soubor schopností v uvedených směrech: uvědomovat si klíčové procesy $\mathrm{v}$ technice (co to je a jak to funguje), umět obsluhovat technické prrístroje a zařízení, umět aplikovat technické poznatky v nových situacích, neustále rozvíjet vlastní technické vědomosti, dovednosti a návyky, umět využívat technické informace a hodnotit je. Pod technickou gramotnost začleňujeme i rovinu emotivní, tedy ovládání a rozvíjení emocí při činnosti s technikou anebo v situacích, do kterých technika vstupuje (srov. Dostál \& Prachagool, 2016).

Zahraniční zkušenosti naznačují, že pojem technická gramotnost se ukázal jako nedostatečný, zejm. v souvislosti s reálnou podobou implementace konceptu STEM do školní praxe. Proto přední odborníci doporučují rozlišovat mezi pojmy inženýrská gramotnost a technická gramotnost (srov. J. Krupczak, J. W. Blake, K. A. Disney, C. O. Hilgarth, R. Libros, M. Mina a S. R. Walk, 2012). Oba pojmy jsou navzájem obsahově propojeny, překrývají se, a potenciál vzniku nesprávného pochopení je větší, než by se na první pohled mohlo jevit.

$\mathrm{V}$ mezinárodním kontextu je třeba upozornit, že dochází k častému zaměňování významů pojmů v souvislosti $s$ anglickým termínem „technology literacy“. Ten bývá rovněž vykládán ve smyslu využití digitálních technologií nebo počítačů. Pro toto chápání navrhujeme užívat již zažité označení digitální nebo počítačová gramotnost.

Situace je o to složitěǰší, že sám pojem technologie (technology) může nabývat různých významů. Obecně jsou rozlišovány čtyři způsoby definování pojmu technologie: v rovině objektové, znalostní, čin-

\footnotetext{
${ }^{2}$ Prakticko-činnostním vzděláváním zde rozumíme aktivity spojené s realizací tematických celků učiva, kdysi v rámci učebnic oficiálně označovaných jako „praktické činnosti“. Byly a jsou zahrnuty pod vzdělávací oblast Člověk a svèt práce (MŠMT, 2017).
} 
nostní a volní (Mitcham, 2001). V nejobecnějším smyslu je technologie chápána jako tvorba a použití artefaktů, ale je třeba mít na zřeteli čtyři hlubší aspekty tohoto jevu. Za prvé, výše uvedený autor vnímá technologii jako soubor objektů zpravidla materiální povahy - stroje, nástroje atp. $\mathrm{V}$ tomto významu se u nás používá označení technika. Dále uvádí, že je možné na pojem technologie nahlížet jako na komplex znalostí. Jedná se o soubor způsobů a postupů spojených s výrobou a užíváním technických objektů. Tento pohled zahrnuje jak rovinu „know-that“, tak i „know-how“. Spadá sem rovněž kreativita. Za třetí, existuje vnímání pojmu technologie $\mathrm{v}$ rovině činnosti, $\mathrm{v}$ jejímž rámci jsou za využití technických znalostí vytvářeny či využívány artefakty. Za čtvrté, existuje další často přehližená dimenze „technologie jako vůle“. V této souvislosti bývají brány $\mathrm{v}$ potaz následující jevy: sociální povaha artefaktů, život v technologickém světě, dopad techniky na přírodu, rozhodování o alternativních technických řešeních, společenské ovlivňování objemu a tempa rozvoje techniky atp. $\mathrm{V}$ poslední době jsou např. velmi diskutovaným tématem etické aspekty robotizace (viz Lin, Abney \& Bekey, 2014; Lin, Abney \& Jenkins, 2017). V širším smyslu můžeme pojem technologie vykládat za jakoukoli modifikaci přirozeného světa, která zohledňuje lidské potřeby. To zahrnuje nejen hmotné produkty, ale také znalosti a procesy nezbytné pro vytvoření a užívání těchto produktů.

Vratme se ale $\mathrm{k}$ inženýrské a technické gramotnosti. Inženýrství je založe- no na aplikaci technických a vědeckých znalostí za současného využití lidských i materiálních zdrojů za účelem uspokojení potřeb lidí. Podstata inženýrství leží $v$ procesu a interdisciplinaritě (srov. Heywood, 2017). Podle prací některých autorů (Krupczak et al., 2012; Blake et al., 2016) lze uvést, že v souvislosti s gramotnostmi se ve zjednodušené formě hovoří o inženýrství jako o „procesu“ a o technice jako o „produktu“. Pomineme-li v kontextu výše uvedeného jisté významové zjednodušení, naskýtá se unikátní př́iležitost $\mathrm{k}$ rozlišení toho, co je podstatou předmětu technika (technická výchova) na základních školách. V jejím rámci je ve velké míře rozvíjena inženýrská gramotnost, tedy analýza technického problému, identifikace podmínek, návrh konstrukce s ohledem na účel a následné praktické konstruování, včetně všech jeho typických fází. Specializované prostory pro tyto činnosti jsou nazývány dílnami nebo laboratořemi. Odlišme tyto inženýrské aktivity od prírodovědného laborování: „science“ je zaměřena na pochopení prírodního světa, zatímco inženýrství na vytváření a modifikaci umělého světa techniky za účelem zlepšení lidské prosperity.

Přirozeně může být oddělování inženýrské gramotnosti od technické považováno za v jistém smyslu umělé. Krupczak et al. (2012) toto připouštějí a zmiňují prostor pro diskusi nad odlišnostmi a analogiemi obou gramotností. Též akceptují skutečnost, že jedna $z$ uváděných gramotností může být považována za součást druhé, tedy inženýrská jako součást technické. 
Rovněž Firman, Rustaman a Suwarma (2016) uvádějí, že technika a inženýrství jsou rozdílné, ale úzce vzájemně propojené. Nutno podotknout, že vymezení inženýrské gramotnosti vzniklo do značné míry jako obranná reakce na aktivity vedoucí k nedoceňování významu prakticko-činnostně pojatého technického vzdělávání na školách ve smyslu inženýringu. V historickém kontextu České republiky i zažité terminologie se jedná o tradiční součást technické gramotnosti ve velké míre rozvíjené $\mathrm{v}$ obecně technickém předmětu, který budeme dále $\mathrm{v}$ souladu s aktuálními trendy označovat názvem Technika. Učivo, se kterým se žáci v rámci tohoto předmětu ve škole setkávají, je v současnosti obsaženo ve vzdělávací oblasti Člověk a svět práce. Uvědomění si této skutečnosti je podstatné, jelikož - jak budeme dále argumentovat - název samotný neodpovídá zcela tomu, co by mělo kurikulum odrážet. Technika je významnou součástí kultury, je to uměle vytvořený svět. Pokud existuje oblast Člověk a príroda, potom je třeba, aby existovala i vzdělávací oblast Člověk a technika. Důvodem je i skutečnost, že svět práce není jen o technických povoláních, ale dotýká se i všech ostatních profesí.

\section{UČIVO O TECHNICE A VÝCHOVA}

\section{K VOLBĚ POVOLÁNí}

Vyučovací předměty je v obecné rovině možné dle jejich charakteru rozčlenit na předměty $s$ převahou teoretického zaměření, předměty s převahou praktického zaměření a předměty s převahou výchovného zaměření. $Z$ hlediska celkové doby strávené žáky ve výuce předměty $s$ převahou teoretického charakteru dominují. Následují předměty výchovné, kam však námi uvažovaný vzdělávací obsah zaměřený na techniku a praktické činnosti není začleněn (NÚOV, 2012), a to navzdory tomu, že obor připravující učitele na jeho výuku byl donedávna namnoze označován jako technická výchova - jak v České republice, tak i na Slovensku. $\mathrm{Na}$ některých pedagogických fakultách u nás dokonce toto označení přetrvává dodnes, kupř. PdF ZČU v Plzni realizuje program „Učitelství technické výchovy pro základní školy“, PdF OU v Ostravě program „Technická výchova pro ZŠs“.

$\mathrm{V}$ podstatě i nadále trvá existence předmětu spadajícího pod oblast Člověk a svèt práce a označovaného jako pracovni činnosti, ${ }^{3}$ dřive i pracovni vyučování. Zejména po revoluci bylo od označení pracovní vyučování a pracovní činnosti upouštěno, ${ }^{4}$ jelikož tyto předměty byly výrazněji zaměřeny na manuální práci, která byla za dob socialismu nadřazována nad práci intelektově založenou. Přitom pracovní výchova poskytuje optimální prostor pro formování pozitivního vztahu žáků k práci. Ti si osvojují různorodé pracovní dovednosti a návyky a pěstují pracovní kulturu. Významné je postupné při-

\footnotetext{
$\overline{3}$ Pod vzdělávací oblast Člověk a svět práce spadají různě zaměřené předměty, jako je príprava pokrmů, pěstitelství, volba povolání atd. My se $\mathrm{v}$ této studii zaměřujeme pouze na předměty obsahově vázané na techniku a s tím spojené praktické činnosti.

${ }^{4}$ Začal se užívat název praktické činnosti. Ten nesla i nová řada učebnic pro základní školy.
} 
vykání si pracovní morálce, která spočívá $\mathrm{v}$ tom, jakým způsob se lidé staví k práci. Výsledkem by měl být nejen kladný postoj k pracovním činnostem a úcta $\mathrm{k}$ práci, ale i přesvědčení, že jakákoli práce má morální prýnos a vnitřně zakotvenou schopnost posílit charakter. Již jsme ale zmínili existenci intelektově založené práce, resp. duševní práce. Nelze jednu nadřazovat nad druhou, jelikož obě jsou stejně hodnotné. Proto je nezbytné, aby byla pracovní výchova realizována $\mathrm{i} v$ převážně naukově založených předmětech.

Zmínili jsme pojem povolání, ${ }^{5}$ se kterým velmi úzce souvisí profesní orientace. Technicky a prakticko-činnostně zaměřný obsah vzdělávání umožňuje svou členitostí a různorodostí žákům přibližit celou řadu povolání. ${ }^{6}$ Svět práce je však velmi rozsáhlý a existuje velké množství povolání. Jen portál Národní soustava povolání (NSP, 2018) jich eviduje přes 2472 včetně podrobné specifikace. Už z tohoto čísla je zřejmé, že neexistuje reálná šance, aby mohly být $\mathrm{v}$ rámci výuky jednoho předmětu přibližženy. Po logické úvaze navíc dospíváme $\mathrm{k}$ názoru, že $\mathrm{k}$ profesní orientaci ${ }^{7}$ musí přispívat všechny vyučované předměty, jelikož jen tak lze umožnit žákům poznat své vlohy a předpoklady $\mathrm{k}$ získání kvalifikace pro výkon dané profese.

Vyjdeme-li z výše uvedeného rozčlenění vyučovacích předmětů, zastavme se krátce u toho, co je myšleno onou převahou praktického zaměření. Sám pojem praxe je možné vymezit jako provádění určité činnosti, konání za účelem získání zkušeností. Zřetelná je dynamika, je opakem teorie. Na pojem praxe však můžeme nahlížet i jako na výsledek lidského úsilí. Poté jí myslíme již konanou činnost, která byla $\mathrm{v}$ minulosti prováděná, a tudíž je danému subjektu známá. Obvykle např. zaměstnavatelé hledají zaměstnance s praxí.

Onu praktičnost lze hledat jednak v osvojování poznatků majících aplikační charakter, tedy takových, které nacházejí uplatnění při provádění činnosti, nebo ve vlastní realizaci činnosti. Při ní jsou uplatňovány poznatky teoretického charakteru získané $\mathrm{v}$ rámci tohoto předmětu anebo předmětů jiných. Praktikování by však mělo mít z logiky věci odlišný charakter od cvičení, která jsou součástí daných předmětů. Např́klad v matematice je procvičována geometrie a prakticky rozvíjena prostorová představivost, ve fyzice výpočet namáhání při silovém působení, ale $\mathrm{v}$ předmětu Technika dochází $\mathrm{k}$ praktickému uplatňování znalostí a dovedností při tvůrčích činnostech blízkých životu a jejich propojování v rozsáhlejší komplexy dovedností. Významnost vedení žáků $\mathrm{k}$ praktickému využití získaných poznatků je dokládána historicky. L. Mojžíšek (1969) uvádí, že nestačí pouze procvičovat

\footnotetext{
${ }^{5}$ Nezaměňujme pojmy povolání a práce.

${ }^{6}$ Krátce se zmiňme o rozdílu mezi zaměstnáním a povoláním. Zaměstnání chápeme jako určitou roli ve světě práce za současné existence zaměstnaneckého vztahu mezi zaměstnancem a zaměstnavatelem. Povolání bývá chápáno podobně jako zaměstnání, avšak bývá spojováno s posláním, $s$ předurčením, $s$ naplněním, $s$ přinášením pocitu radosti z vykonávané práce. Může existovat i mimo pracovní poměr, např. jako živnost.

${ }^{7}$ Čtenáŕe dále odkazujeme na práce P. Hlad’a $(2012,2013)$.
} 
dovednosti izolovaně od života, je nutno procvičovat způsoby jejich praktického použití. Tohoto požadavku si všímá i J. A. Komenský (tamtéž), který míní, že vedle rozumového poznání a rozvíjení paměti je nutno se domáhat i výcviku řeči a ruky, že je třeba také prakticky pracovat (srov. Komenský, 1951).

Do prakticky založených činností namnoze vstupují uměle vytvořené předměty, nástroje, stroje či zařízení, souhrnně označované jako technika. Jsou-li činnosti založeny převážně na ručních aktivitách, poté můžeme hovořit o remesle. Provádění řemeslných prací ve školách napomáhá rozvinout rukodělné schopnosti žáků, jejich um, a poznat celou řadu povolání, což je významné pro jejich další profesní orientaci i osobní život. V období robotizace, umělé inteligence a celé řady moderních technologií se může jevit rozvoj manuálních dovedností žáků jako překonaný, což je však mylný závěr. Řemeslná povolání nelze $\mathrm{v}$ převážné míre automatizovat, jelikož se zpravidla neodehrávají na stálém místě a při řešení úlohy vyžadují zvažování mnoha okolností. Moderní technologie $\mathrm{v}$ mnohem větší míre ohrožují povolání jako účetní či administrativní pracovníci. Ne každý se bude věnovat řemeslu na profesionální úrovni. Nicméně pro zvládání běžných životních situací jsou řemeslné dovednosti v podstatě nezbytné a je třeba, aby si je bylo možné osvojit $\mathrm{v}$ rámci všeobecného vzdělání. To by však zcela nepostačovalo, na úrovni řemeslnictví nelze setrvávat, byt’ ze zahraničí známe např. „švédský slöjd“.
V řemeslnictví je nástroj a náčiní pouze doplňkem člověka (Gasset, 2011), proto řemesla budou existovat i nadále a prýiprava na jejich výkon vyžaduje specifický trénink dovedností, zpravidla realizovaný na středních školách. Naproti tomu, v případě dělnických profesí se do popředí dostává stroj. Ten již není tím, kdo pomáhá člověku, naopak je to člověk, který kooperuje se strojem, pomáhá mu a doplňuje ho v operacích, jež (zatím) nedokáže uskutečňovat. Zde je zřetelné, že škola se nemůže tolik orientovat na rozvoj dovedností, které mohou do budoucna převzít stroje.

Vzdělávání na základních školách musí být $\mathrm{v}$ prrípadě technického vzdělávání zaměřeno na výchovu jedinců, kteří dokáží běžné životní situace vyžadující aplikaci techniky správně vyhodnotit a techniku využít - at již kreativním, nebo rutinním způsobem. Rozvoj technické kreativity je mimořádně cenný, avšak stejně tak je podstatné umět využívat techniku obvyklým způsobem. Ne vždy je třeba objevovat nová řešení. $S$ tím souvisí sebehodnocení (srov. Částková \& Provázková Stolinská, 2016). Jedinec musí v běžném životě umět posoudit své technické znalosti a dovednosti, jelikož si pokládá otázky: Zvládnu to, vím, umím, chci, mám potřebné nástroje..., anebo je třeba využít služeb profesionála?

Technické a prakticko-činnostně pojaté vzdělávání má rovněž relaxační funkci. Manipulace s nástroji, vytváření něčeho zcela nového anebo jen přetváření již existujících věcí přináší potěšení a umožňuje odpočinek od kognitivní zátěže, nastavení rovnováhy mezi duševními a fyzickými 
aktivitami. Technické činnosti se podobně jako umělecké či výtvarné aktivity namnoze stávají výplní volnočasových zájmových aktivit.

\section{REALIZAČNÍ PODMÍNKY VÝUKY UČIVA O TECHNICE}

Ze své povahy je výuka technických a prakticky založených aktivit náročná, a to nejen $\mathrm{z}$ pohledu materiálního zajištění a dodržování hygienických a bezpečnostních zásad, ale především z hlediska profesních kompetencí učitele. Od toho se čím dál více očekává angažovanost při tvorbě školního kurikula. Rámce očekávaných výstupů pouze vymezují to, čím mají žáci po ukončení dané etapy vzdělávání disponovat, ale podoba konkrétního obsahu výuky je nezř́́dka ve větší míře určována anebo alespoň ovlivňována př́mo učitelem. Petr Knecht (2007) v podobném duchu uvádí, že finální podoba každé vyučovací hodiny zcela záleží na schopnostech, zkušenostech a motivaci každého učitele.

Předměty založené na praktických činnostech spočívají ve výrazně větší míre $\mathrm{v}$ osvojování nových nebo $\mathrm{v}$ dalším rozvoji již částečně získaných dovedností žáka. K tomu jsou zapotřebí především procedurální znalosti, které se týkají postupů a způsobů provádění činností, přičemž konceptuální znalosti sehrávají též významnou roli. $\mathrm{Na}$ jejich úrovni však není možné ve výuce setrvat, taková výuka by jen stěží vedla k žádoucímu rozvoji praktických dovedností spojených s prováděním rutinních technických činnos- tí nebo úspěšným řešením technických problémů. Jejich řešení nezřídka vyžaduje současné nasazení intelektových, senzorických i motorických dovedností. Ty by měly být postupně precizovány a automatizovány a přejít $\mathrm{v}$ návyky, což umožňuje úsporné provádění technických činností. Ovšem osvojování návyků je náročné na čas, na poskytování zpětné vazby učitelem i na motivaci žáků samotných. S tím blízce souvisí nezbytnost pedagogicko-psychologického vzdělání učitele, jelikož tréning procedurální paměti není jednoduchou záležitostí. Tím spíše, mohou-li žáci do školy přicházet i s nesprávně osvojenými dovednostmi a při provádění činností zjevně vykazovat nevhodné návyky (srov. Doulík \& Škoda, 2010).

Výše uvedené klade na učitele vysoké požadavky, a proto musí být technické a prakticko-činnostně založené předměty vyučovány profesionály disponujícími tzv. didaktickými znalostmi obsahu. Ty nejžretelněji odlišují učitele od oborového specialisty $\mathrm{v}$ tom, jak rozumí oborovým obsahům a jak je schopen je zprostředkovat a komunikovat směrem $\mathrm{k}$ různým adresátům (Janík, 2009). Připravuje a v průběhu realizace výuky každým okamžikem utváří vhodné edukační prostředí, optimálně zajištující všestranný rozvoj osobnosti žáka ve směru $\mathrm{k}$ technice tak, aby k ní a jejímu praktickému využívání v životě získal správné postoje. Nelze opomenout ani rozvoj technického myšlení.

Odhlédneme-li od nároků kladených na učitele, vyplouvají na povrch nároky na materiální zajištění výuky. Pro převážně naukové předměty je typické, že je lze 
vyučovat v běžně vybavených učebnách. Oproti tomu technické a prakticko-činnostní předměty, mají-li být vyučovány kvalitně, vyžadují vhodné nástroje, nářadí a prostory. Navíc je třeba zajistit technický materiál, který do prakticko-činnostních aktivit vstupuje jako významná složka. Bez materiálu nelze tvořit a konstruovat, technické představy by i nadále zůstaly představami. Jejich pouhé zachycení na papír nebo pomocí počítače je nedostatečné, jelikož bychom setrvávali v kognitivní rovině. Poté by technické a prakticko-činnostní vzdělávání ztrácelo na svém smyslu. Je však třeba připustit, že takto zaměřené vzdělávání je možné při vhodném metodickém uchopení realizovat $\mathrm{v}$ běžné třídě. Př́tomnosti nástrojů, nářadí a technického materiálu se však ani $\mathrm{v}$ tomto př́ípadě nelze vyhnout. Možným řešením jsou rovněž tzv. sdílené dílny, které využívají školy nedisponující vhodnými prostory.

\section{ZÁVĚR}

Odborné vzdělávání sehrává klíčovou roli v př́ípravě na výkon budoucího povolání bez ohledu na konkrétní zaměření. Směřuje k získání znalostí, dovedností a kompetencí, které odpovídají určité kvalifikaci a které je možné přímo uplatnit na trhu práce. $\mathrm{K}$ tomu mohou výrazněji napomoci vlohy a zájmy žáků. Proto je nezbytné, aby již v rámci základního vzdělávání existoval dostatečný prostor pro jejich objevení a další řízený rozvoj. Je podstatné si uvědomit, že tak jako jsou vlohy i zájmy dětí různorodé, musí být i obsah vzdělávání pestrý. Výuka techniky na základní škole vytvárí prostor $\mathrm{k}$ tomu, aby si žáci uvědomili, které činnosti je baví, o které mají zájem, ve kterých jsou zruční a kterým by se $\mathrm{v}$ budoucnosti $\mathrm{v}$ dalším studiu a ve své profesní práci chtěli věnovat (Hašková \& Bánesz, 2015). Situace, kdy jsou vlohy a zájmy dítěte ve shodě s profesí, na kterou se v rámci odborného vzdělávání připravuje, můžeme označit za ideální. Školní praxe by měla usilovat o dosažení tohoto stavu.

Nastolme i otázku prožívání školního úspěchu. Škola musí poskytovat př́ležitosti k tomu, aby mohli být všichni žáci úspěšní. Není třeba, aby úspěch prožívali vždy a ve všech předmětech, nicméně každý žák by měl mít možnost vyniknout. Jak uvádí i Portešová (2018), nadané dítě nemusí být úspěšné ve všech školních oblastech, jeho schopnosti mohou být nerovnoměrně rozloženy i rozvinuty, a to až do té míry, že může $\mathrm{v}$ jistých oblastech podávat i průměrné či podprůměrné výkony. Existuje celá řada druhů nadání - rozumové, umělecké, manuální, pohybové, sociální (srov. Hř́bková, 2009; Machů, 2010; Kovářová, 2013). Proto je nezbytně nutné, aby škola dokázala nabídnout takový prostor, kde bude moci vyniknout a prožívat úspěch i technicky či rukodělně nadaný žák.

$\mathrm{K}$ tomu je nezbytné, aby školní kurikulum zahrnovalo obsah vzdělávání odpovídající všem složkám lidské kultury, tím více, má-li být vzdělávání na základních školách všeobecným. Poznatky o technice a technické dovednosti představují s ohledem na aktuální společenské a technologické změny významnou vzdělávací oblast. Ta je jistým způsobem uni- 
kátní v propojení na praktický život a prostoru pro mezipředmětovou poznatkovou integraci, která bývá $\mathrm{v}$ posledních letech zdůrazňována vytvářením komplexněji pojatých vzdělávacích konceptů (např. lze uvést $\mathrm{v}$ České republice známé polytechnické vzdělávání nebo v zahraničí STEM).

Nejde o to eliminovat věci tradiční, které mají uplatnění i v budoucnosti, je však mimořádně nezbytné reagovat na nové trendy a obsah vzdělávání uvědoměle inovovat (Dostál, 2018). To již dřive naznačil i Bruens (2012), který uvádí, že učitelé techniky mají učit žáky, jak používat řadu praktických nástrojů, od tradičních až po vysoce moderní.

Pro technické a prakticko-činnostní vzdělávání je prríznačný princip společného učení se mozkem, srdcem a rukama.
Ten by neměl být opomíjen ani $\mathrm{v}$ moderním pojetí vzdělávání. Žáci potřebují prostor $\mathrm{k}$ tomu, aby se naučili, jak riskovat a stát se vynalézavými, inovačními, podnikatelskými. Musí mít možnost rozvíjet technické znalosti, praktické dovednosti, technickou představivost a kreativitu a umět je aplikovat v každodenním životě. Smyslem je rozvíjet pochopení techniky samotné, její podstaty, a rovněž procesů inženýrského návrhu $s$ cílem řešit běžné problémy a potřeby lidí (NAGB, 2018). Je nepř́ípustné o technice pouze sdělovat teoretické poznatky bez následných praktických činností. Právě ty mohou být prostředkem pro odhalení technického nadání a $\mathrm{k}$ dalšímu profesnímu orientování žáka ve směru $k$ technickým a řemeslným povoláním.

\section{Literatura}

Ankiewicz, P. (1995). The planning of technology education for South African schools. International Journal of Technology and Design Education, 5(3), 245-254.

Blake, J. W., Cheville, A., Disney, K. A. et al. (2016). Philosophical and educational perspectives on engineering and technological literacy, III. (Online). Electrical and Computer Engineering Books. Dostupné z http://lib.dr.iastate.edu

Bruens R. (2012). Industrial arts teacher - career information for educators. (Online). Dostupné $\mathrm{z}$ https://education.cu-portland.edu

Cipro, M. (1996). J. H. Pestalozzi a výchova. Praha: vl. nákl.

Částková, P., \& Provázková Stolinská, D. (2016). Hodnocení a sebehodnocení žáků primární školy v technické výchově v genderovém kontextu. TVV, 9(1), 28-36.

Dixon, R. A. (2013). Trends and issues in technology education in the USA: Lessons for the Caribbean. Caribbean Curriculum, 21(1), 47-79.

Dostál, J. (2018a). Moudrost rukou aneb K realizaci kvalitní výuky techniky na školách potřebujeme kvalitní učitele. In Trendy ve vzděláváni: Technika, informatika a inovace ve vzdélávání napríč obory (s. 11-16). Univerzita Palackého v Olomouci.

Dostál, J. (2018b). Ve školní praxi užívané názvy pro označení vyučovacích předmětů zaměřených na techniku a informatiku. In Trendy ve vzděláváni: Technika, informatika a inovace ve vzděláváni napríč obory (s. 19-22). Univerzita Palackého v Olomouci. 
Dostál, J., \& Prachagool, V. (2016). Technické vzdělávání na křižovatce - historie, současnost a perspektivy. Journal of Technology and Information Education, 8(2), 5-24.

Doulík, P., \& Škoda, J. (2010). Prekoncepce a miskoncepce jako součást dětských pojetí a jejich psychogeneze. In J. Škoda, P. Doulík et al. Prekoncepce a miskoncepce v oborových didaktikách. Ústí nad Labem: UJEP

Firman, H., Rustaman, N. Y., \& Suwarma, I. R. (2016). The development of technology and engineering literacy through STEM-based education. In Advances in Social Science, Education and Humanities Research (s. 209-212). International Conference on Innovation in Engineering and Vocational Education 2015.

Gasset, O. J. (2011). Úvaha o technice. Praha: Oikoymenh.

Hašková, A., \& Bánesz, G. (2015). Technika na základných školách - áno alebo nie. Praha: Verbum.

Heller, J., \& Hotová, T. (2019). Máme tu generaci nešikovných chirurgů, říká přednosta z VFN. Viní mobily a počítače. Aktuálnè.cz. 19. 3. 2019.

Heywood, J. (2017). The human side of engineering. Synthesis Lectures on Engineering, 11(1), $1-166$.

Hlad'o, P. (2012). Profesni orientace adolescentü: pohledy z teorií a výzkumů. Brno: Konvoj.

Hlad’o, P. (2013). Rozhodováni žákủ absolventských ročníkủ základnich škol o dalši vzdèlávací a profesni dráze. Mendelova univerzita v Brnè.

Hříbková, L. (2009). Nadání a nadání: pedagogicko-psychologické prístupy, modely, výzkumy a jejich vztah ke školské praxi. Praha: Grada.

Ingerman, A., \& Collier-Reed, B. I. (2011). Technological literacy reconsidered: A model for enactment. International Journal of Technology and Design Education, 21(2), 137-148.

ITEA. (2007). Standards for technological literacy: Content for the study of technology. 3. vyd. Reston: ITEA.

Janík, T. (2009). Didaktické znalosti obsahu a jejich význam pro oborové didaktiky, tvorbu kurikula a učitelské vzdělávání. Brno: Paido.

Knecht, P. (2007). Didaktická transformace aneb od didaktického zjednodušení k didaktické rekonstrukci. Orbis scholae, 2(1), 67-81.

Komenský, J. A. (1951). Didaktické spisy. Praha: SPN.

Kovářová, R. (2013). Nadaný žák v kontextu doby. Ostravská univerzita v Ostravě.

Kropáč, J. (2004). Technika, technické vědy, technická výchova. In J. Kropáč, Z. Kubíček, M. Chráska a M. Havelka, Didaktika technických předmètů (vybrané kapitoly). Univerzita Palackého v Olomouci.

Krupczak, J., Blake, J. W., Disney, K. A. et al. (2012). Defining engineering and technological literacy. In Proceedings of Annual Conference of the American Society of Engineering Education (Paper 5100), San Antonio, Texas.

Lee, S. M., \& Trimi, S. (2018). Innovation for creating a smart future. Journal of Innovation \& Knowledge, 3(1), 1-8. 
Lin, P., Abney, K., \& Bekey, G. A. (2014). Robot ethics: The ethical and social implications of robotics. MIT Press.

Lin, P., Abney, K., \& Jenkins, R. (2017). Robot ethics 2.0: From autonomous cars to artificial intelligence. Oxford University Press.

Machů, E. (2010). Nadanýžáa. Brno: Paido.

Mitcham, C. (2001). Philosophizing about technology: Why should we bother? (Online). Dostupné z http://ethix.org

Mojžíšek, L. (1969). Formalismus v pracovních dovednostech mládeže. In Sborník prací Filosofické fakulty Brnènské university (s. 89-112).

MŠMT. (2017). Rámcový vzdèlávaci program pro základni vzdèlávání. Praha.

NAGB. (2018). Technology \& engineering literacy framework for the 2018. National assessment of educational progress. (Online). Dostupné z www.nagb.gov

NSP. (2018). Národni soustava povolání. (Online). Dostupné z www.nsp.cz

NÚOV. (2012). Stupně hodnoceni prospěchu a chováni v prípadè použití klasifikace a jejich charakteristiku, včetně predem stanovených kritérií. (Online). Dostupné z www.nuov.cz

Portešová, Š. (2018). Proč se má učitel věnovat nadaným dětem? Jen jeden dỉvod z mnoha... (Online). Dostupné z www.nadanedeti.cz

Potgieter, C. (2012). Linking learning activities and assessment activities to learning outcomes and assessment standards when teaching technology: A case study. International Journal of Technology and Design Education, 23(4), 969-986.

Pudi, T. I. (2007). Understanding technology education from a South African perspective. Pretoria: Van Schaik.

Ramirez, G. N. K., \& Perez, M. L. F. (2015). Incidencia del abordaje de una cuestión socio-científica en la alfabetización científica y tecnológica de jóvenes y adultos. Praxis \& Saber, 6(11), 87-114.

Skalková, J. (1999). Obecná didaktika. Praha: ISV.

Spitzer, M. (2014). Digitálni demence. Brno: Host.

Štofa, J. (1992). O všeobecnej technickej vzdelanosti mládeže. In Technické vzdelávanie jako súčast všeobecného vzdelávania (s. 30-33). Banská Bystrica: UMB.

Tondl, L. (2009). Člověk ve světě techniky: nové problémy filozofie techniky. Liberec: Bor.

Urbánek, P. (2017). Smysl má bránit jakékoli vzdělávací obsahy. Pedagogika, 67(3), 306-310. Van Rensburg, S. J., Myburgh, C. P. H., \& Ankiewicz, P. (1996). Curriculum development for technology in South Africa: Gender issues. GASAT 8 Conference, Ahmedabad, India.

doc. PhDr. PaedDr. Jiři Dostál, Ph.D.

Univerzita Palackého v Olomouci, Pedagogická fakulta, Katedra technické a informačni výchovy; e-mail:j.dostal@upol.cz 
DOSTÁL, J. The Importance of Incorporating Technical and Practical Subject Matter into the Curriculum of Basic Schools

Society today is experiencing a very intense wave of global changes at an unprecedented speed, scale and volume. These are above all technological and economic changes that have a fundamental effect on the form of society. The tempo of the development and implementation of technologies based on robotics, artificial intelligence and information systems is having an impact on the whole range of fields of human activity (even those not directly connected with technology) and in addition to this the expansion of the digital and shared economy is creating new educational needs to which it is important to respond without delay. It is important that we prepare future generations for life in the new conditions, and the educational system plays an important role here. The new demands for innovation relate to all levels of education, but we shall focus above all on basic schooling in the conditions of the Czech Republic.

Logically questions must arise as to whether the currently indicated developmental trends are sufficiently fundamental to warrant curricular transformation of the form of education, and whether the right time for its realisation has arrived. We look for answers through the comparison of international experience with an emphasis on cardinal categories closely linked to the teaching of technical and practical-activity subjects. We likewise analyse the planning and executive documents associated with the changes underway in education including key studies both in the subject didactics and in educational theory. Taking a synthetic approach we deduce and discuss the drivers for an innovative form of teaching material on technology at basic schools, for this is a factor that increasingly cannot be overlooked in the creation of the complex of competences essential for the life of the individual in modern society.

Keywords: technical education, curriculum, elementary school, STEM, technical creativity, practical training, technical literacy, vocational guidance. 